TechnoLEARN: An International Journal of Educational Technology

TechnoLEARN: 9(2): 83-86, December 2019

DOI: 10.30954/2231-4105.02.2019.4

(C2019 New Delhi Publishers. All rights reserved

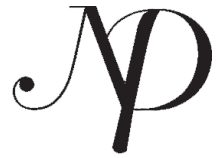

\title{
Promoting Student-Centered Learning in Experiential Education
}

\author{
Prof. (Dr.) Archana Dinesh \\ Arts and Humanities Department, Sage University, Indore, M.P. India \\ Corresponding author: archanadinesh2012@gmail.com
}

\begin{abstract}
Teacher-centered experiential education has learning value, it is not nearly as beneficial as student-centered experiential education. It is clearly time for the profession to raise awareness, increase discussion and take action in order to resolve this incongruence between what experiential education claims to value and how experience-based learning is delivered in practice.
\end{abstract}

Keywords: Experiential Educators, Student-centered learning, Learning environment

Experiential educators claim to value student-centered learning, yet the values, as evidenced in practice, are often teacher-centered. Student-centered learning is not a new idea. In general, it involves reversing traditionally teacher-centered learning and places students at the center of the learning process. Emerging brain research validates what experiential educators have always known-students learn best through experiential and student-centered approaches. How can teachers make experiential learning more student-centered? The seven suggestions that follow are values, tips and techniques the author has gathered from personal experiences and the literature.

1. The first suggestion re-iterates the need for experiential educators to recognize that a change from teacher to student-centered learning requires both awareness and conscious effort to initiate and sustain dialog about this problem. Thus, we are comfortable with students looking to teachers for information, answers, guidance, affirmation, and permission to speak. Thus, re-socialization into student-centered values and methods involves awareness, commitment, conscious effort, practice, reflection on practice, and continuous improvement efforts. 
Y

Dinesh

2. A second suggestion is for experiential educators to promote student-centered learning by embracing values similar to Paulo Freier's approach to education where teachers and students transform learning into a collaborative process. The Freier approach is based on the belief that students can find their own authentic voice, and they create knowledge through critical encounters with reality and ideas. While an in-depth study of Freier's and Shor's works will certainly provide the reader with greater familiarity of Freier's techniques than is possible within the scope of this article, a summary of their educational values, in the following section, is illuminating. Frier and Shor's educational values. Freier promotes the use of dialog in place of teacher-led discussion, because through dialog, teachers and students reflect together on what they know, and do not know, and can act critically to transform reality. Dialog implies the absence of authoritarianism and is an epistemological position-in dialog, the teacher does not own the object of study; rather, the students stimulate the teacher's curiosity, and he/she brings enthusiasm to the students. Together, then, they can illuminate the object of learning. Dialog requires that students participate critically in their own education. This does not mean everyone has to speak, but rather students should be listening carefully to both the teacher and to each other. Students should have the right to speak or to pass, because requiring a turn at talk is coercive. Remarks should be addressed to other students, as well as to the teacher. Shor (1989) suggests that teachers encourage this behavior by breaking eye contact with students who are speaking in order to encourage students to address the group more generally. Freier's approach fits well within experiential education, in part, because itrequires students to have prior experiential contact with the object of learning before dialog. 3. A third suggestion is for experiential educators to rely less on the standard practice of talk circles and more on creative techniques to facilitate student reflection. There are three problems with using talk circles for facilitating reflection on experience: (a) Talk circles provide a familiar teacher-centered environment that encourages the teacher to direct the learning process through questioning, validating, paraphrasing, and allocating turns at talk; (b) the emphasis on the importance of circular talk/debriefing in experiential programs has resulted in a decrease in the importance of hands-on experience and (c) the use of talk, and the accompanying idea that talking about an experience is necessary for learning to occur, separates experience into "doing" and "thinking" parts which often values thinking over doing. Experiential educators can learn about alternatives to talk circles by familiarizing themselves with guides to alternative reflection activities. Greenaway (1993) described many reflection alternatives that do not rely on teacher-led talk sessions including art, drama, dance, poetry, writing, storytelling, photography, presentations, or repeating the same activity.

4. A fourth suggestion for experiential educators who choose to use talk circles is to rethink the role of the teacher in verbal facilitation sessions. This will assist the teacher in recognizing the active and influential role they play in determining what is supposed to be learned. Teachers need to be more aware of the tendency for imbalance in knowledge and power 
relationships that typically occurs during talk circles and consciously do the following: (a) avoid prescribing acceptable student responses; (b) have students restate their own responses when clarity is needed (or at minimum, get agreement that the teachers' restatement was accurate); (c) genuinely listen to students; and (d) get students to talk to, and listen to, each other by using verbal and non-verbal techniques that encourage these behaviors. For example, the teacher can re-direct a student who speaks directly to her to speak to the group instead. 5. A fifth suggestion is for experiential educators to let students have a role in facilitating their own experiences. This is especially important in educational environments where teachers are not likely to acquire a complete and accurate needs assessment, which is essential forethical application of higher generations of facilitation such as frontloading, isomorphic framing, indirect frontloading, and hypnotic language. Also, students in therapeutic programs, where facilitators tend to rely more on prescriptive (teacher-centered) methods, will likely find self-facilitation extremely beneficial. All students, regardless of the experiential program's mission, can benefit from developing self-facilitation skills and becoming self-reliant learners. Wilsonsuggested empowering students by: (a) listening to them; (b) allowing them to set individual and group goals; and (c) allowing them to make choices about activities, how to respond to tasks, and when to, and when not to, undertake an experience.

6. A sixth suggestion is for experiential educators to begin a program by assessing both teachers and students to the extent possible. A thorough needs assessment provides an important foundation on which to build a program's goal to create a collaborative learning environment. Bacon noted, "It is always important to know where the students are coming from before trying to lead them somewhere else". Priest and Gass acknowledged that teachers should always do their homework by finding out about the group's needs and objectives in advance. Shor pointed out that in order to operationalize a student-centered learning experience the teacher must begin by researching both self and students. In so doing, the teacher is assessing what resources and liabilities the teacher and the students bring to the learning environment. A part of good, student-centered, practice involves the teacher constantly assessing the group and their own reactions while an experience is on-going.

7. A seventh suggestion is for experiential educators to use prescriptive and advanced generations of facilitation techniques, including metaphor, direct frontloading, isomorphic framing, indirect frontloading, and hypnotic language, only in experiential programs when teachers are highly trained and it is possible to get a complete and accurate needs assessment. In summary, these seven suggestions represent a collection of specific actions experiential educators can take to ensure their facilitation practices are more student-centered.

\section{Implications for Program Development and Facilitator Training}

Most experiential programs engage in continuous improvement efforts and it makes good sense to place student-centered facilitation on programs' agendas. For example, as a part of 
P

Dinesh

improvement efforts, teachers could use brainstorming and discussion to: (a) Identify ways that the program and/or teachers are currently using teacher and student-centered facilitation techniques. (b) Identify where student-centered techniques fit best within the program. (c) Brainstorm creative ideas for student-centered activities/methods that can be utilized. (d) Teachers should practice, share results, reflect, and refine facilitation approaches.

Ideally, both teachers and students will grow through this process. It is especially important to incorporate concepts from student-centered facilitation into experiential educator training programs because it is newly trained teachers who are particularly vulnerable to relying on teacher-centered approaches.

\section{CONCLUSION}

One can trace the evolution of facilitation and reflection, as it relates to the balance of teacher and student power in experiential programs, from student-centered to teacher-centered, and back to student-centered models. While teacher-centered experiential education has learning value, it is not nearly as beneficial as student-centered experiential education. It is clearly time for the profession to raise awareness, increase discussion and take action in order to resolve this incongruence between what experiential education claims to value and how experiencebased learning is delivered in practice.

\section{REFERENCES}

Bacon, S. 1983. The conscious use of metaphor in Outward Bound. Denver, GO: Colorado Outward Bound School. Menand, L. 2001. The metaphysical club. New York: Farrar, Straus and Giroux.

Priest, S. 1996. The effect of two different debriefing approaches on developing self-confidence. Journal of Experiential Education, 19(6): 40-42.

Shor, I. and Freier, P. 1987. What is the "dialogical method" of teaching? Journal of Education, 169(3): 11-31.

Sugerman, D.A., Doherty, K.L., Garvey, D.E. and Gass, M.A. 2000. Reflective learning: Theory and practice. Dubuque, IA: Kendall/Hunt. 